\title{
Resensi
}

\section{"Apa Yang Tidak Dapat Dicapai Seluruhnya, Jangan Ditinggalkan Seluruhnya"}

\author{
JudulBuku : Tidak Syarinya Bank Syariah di Indonesia \\ Penulis : Zaim Saidi \\ Penerbit : Delokomotif \\ Tempat Terbit : Yogyakarta \\ Tahun Tewrbit : 2010 \\ Tebal :328halaman
}

\section{Pengantar}

Judul di atas merupakan terjemahan dari salah satu doktrin fiqh yang sangat populer, yakni ma la yudrak kulluh, la yutrak kulluh. Doktrin figh atau legal maxim tersebut merupakan representasi dari keharusan adanya ikhtiar dan larangan terhadap keputusasaan jika upaya yang dilakukan belum sepenuhnya merepresentasikan capaian yang semestinya. Namun, doktrin atau kaidah tersebut bukan tanpa kondisi, karena doktrin ini dapat diimplementasikan ketika upaya yang dilakukan sudah optimal (bahasa Qur'annya "mastata'tum"), serta didasari keihklasan. Jauh dari sekedar sikap apologetik dan oportunistik.

Kelahiran bank syariah adalah sebuah kompromi yang memang agak terpaksa. Mengapa disebut kompromi, karena bank dalam konsep dan praktek yang diinisiasi oleh negara Barat, baru bersentuhan dengan umat Islam sejak adanya kolonialisme. Artinya, apa yang pernah dirintis dan dilakukan oleh umat Islam terkait dengan praktek komersial dan transaksi ekonomis-finansial pada masa Nabi yang kemudian berlanjut sampai dengan akhir masa kejayaan Islam (sekitar abad 13), terputus dan kemudian negeri muslim masuk dalam era kolonialisme. Baru kemudian, sejalan dengan sekularisasi massif yang diakibatkan proses kolonialisasi itu, dari para kolonial lah orang Islam mengenal konsep perbankan modern dengan berabagai varian produk dan tata operasionalnya, yakni sekitar 1920-an.

Singkatnya, umat Islam pun kemudian mengenal dan terlibat dengan perbankan yang ditransformasikan oleh kolonial. Sampai di sini sebenarnya sudah mulai terjawab, mengapa format kelembagaan bank syariah kurang ideal. Dalam kondisi yang tidak ideal tersebut, orang Islam tidak dapat menutup mata bahwa Quran melarang riba, yang bentuk rilinya adalah bunga bank. Sedang di satu sisi, orang Islam juga sangat berat untuk tidak melakukan praketk perbankan modern, karena berbagai kebutuhan transaksi yang memang sudah terformatsedemikian rupa untuk selalu memanfaatkan fasilitas yang ditawarkan oleh perbankan modern.

\section{Skeptisisme terhadap perbankan syariah (Islam)}

Buku karya Zaim Saidi yang berjudul Tidak Syar'inya Bank Syariah di Indonesia memang bukan yang pertama muncul terkait dengan keraguan akan perbankan syariah (Islam). Skeptisisme tentang kesyariahan bank Islam itu juga pernah ditulis oleh berbagai pemikir. Muhammad Anwar (2006) telah menulis sebuah buku serta 
artikel yang bertajuk Islamicity of Islamic Banking Practice, yang mendiskusikan sebagian produk perbankan, di Malaysia khususnya, dan dia berpendapat bahwa produk yang ditawarkan perbankan Islam masih dipertanyakan kepatuhannya pada ajaran Islam atau prinsip syariah. Meski dua produk utama yang disasar, yakni bai al-inah dan bai al-dain, (yang ini merupakan bagian dari murabahah), tetapi sebenarnya kritik itu dapat juga diarahkian untuk semua perbankan syariah.

Lebih dulu muncul dari itu, Abduliah Saeed (1996)juga mengkritik pendekatan terhadap praktek perbankan Islam. Dia berpendapat bahwa perbankan Islam hari ini tidak bisa menghapuskan diri dari bunga (interest). Benar bahwa bunga telah disingkirkan dari kontrak yang diterapkan, tetapi kalkulasi profit yang diambil masih menyandarkan pada benchmark suku bunga. Sehingga menurutnya, ini hanya merupakan nama baru bagi "bunga" yang karenanya, penamaan dengan label "Islam" tidak dapat diterima selama tidak mencerminkan citarasa keadialan, atau yang dia sebut dengan; equity $y_{j}$ justice and fairness.

Memang, dalam karya Zaim Saidi tersebut ada hal yang dapat membedakan dengan karya lainnya, yakni dilengkapi dengan upaya solusi dari masalah, meski solusi ini nanti akan menjadi catatan juga dalam pembahasan berikut.

\section{Ksyari'ahan, antara legalisme dan utilitarianisme}

Menurut Zaim Saidi, tidak syar'inya bank syariah karena lima faktor: pemakian uang kertas, selingkuh kepentingan, pengingkaran atas tujuan esensial muamalat yakni kepastian dan keadilan bertransaksi, dipraktikkannya penciptaan kredit dan berlakunya time value of money, soal kepemilikan dan terakhir adalah hak dan kekuasaan dalam pengambilan keputusan (hlm. 194-195). Penulis buku juga, sependapat dengan Prof. Ahamed Kameel Mydin Meera, menyatakan bahwa dengan telah jelasnya alasan akademis bahwa perbankan syariah itu tidak berbeda dengan perbankan konvensional, maka menjadi tidak logis jika pengharaman bank konvensional itu tidakjuga diberlakukan pada perbankan syariah.(hlm 201-202).

Perlu diperhatikan bahwa pengharaman secara kasar ini justeru menunjukkan pengabaian terhadap sifat dasar dari suatu sistem hukum. Hukum Islam, dalam pengertian figh, adalah sebuah instrumen hukum, yang karenanya sebagaimana sifat yang terlekat dengan hukum, bahwa di satu sisi dia harus menawarkan kepastian, tapi di satu sisi harustah menawarkan keadilan. Keadilan dan kepastian adalah dua hal yang sulit direkonsiliasikan. Karena kepastian terletak dalam teks, sedangkan keadilan adalah cita rasa yang terkadang tidak dapat terwakili dalam ungkapan hukum. Dalam khazanah hukum apa saja, ini adaiah hal yang lumrah. Ini adalah pergulatan antara legalisme dan utilitarianisme, antara kepastian hukum dengan manfaat dariu suatu kepentingan hukum. Para imam madzhab dalam hukum Islam, juga mengalami efek dari dua sisi kepentingan tersebut. Maka muncullah kemudian Imam Syafi' yang tekstualis dan Imam Hanafi yang lebih mengutamakan rasionalitas.

Maka dari itu, kemudian yang harus dibangun adalah spirit atau ruh dari bagaiamana orang berhukum dengan hukum syäriah. Karena di tangan orang yang tidak memiliki spirit syariah, aturan fiqh dapat saja dijungkirbalikkan sehingga seakan-akanjauh dari nilai kemashlahatan yang diinginkannya.

Ketika dikatakan bahwa bank syariah bertentangan dengan syariah, maka pertanyaannya, aspekhukum atau moral. Jika dalam pengertian hukum, hukum akan menentukan bahwa selama dilakukan dalam akad yang benar, maka dapat dihukumi benar. Tapi tidak jarang bahwa ketetapan hukum itu tidak mampu mengakomodasi kemaslahatan yang diinginkan. Di sini kemudian diskusi masuk dalam wilayah bagaimana mashlahat (maqashid syari'ah) itu diterjemahkan. Mashlahat itu untuk siapa, pemodal atau nasabah, tentu ini juga memerlukan diskusi yang panjang. 
Lain dari pada itu, harus dipahami juga bahwa transaksi syariah yang diaplikasikan dalam perbankan syariah pun.sebenarnya adalah transaksi-transaksi umum dalam muamalah, yang tidak terbatasi atau dilakukan dalam sebuah institusi finansial. Karena itulah, kontrak-kontrak tersebut terkadang terasa dipaksakan, karena sebenarnya kurang kompatibel. Namun sekali lagi, karena itulah isntrumen yang ada yang dapat direkonssiliasikan dengan sistem perbankan modern. Sehingga pengharaman tersebut membawa pilihan pada: "memperbaiki" yang ada atau "meninggalkan: yang ada. Pengharaman berarti adalah "meninggalkan" yang ada. Tentu saja harus disertai jawaban yang harus menyelesaikan problem yang lebih bersifat transisional, jika tidak, maka akan muncul banyak kesulitan.

\section{Solusi: kurang menjawab keperluan kekinian.}

Solusi atas problem tidak syar'i nya perbankan syariah yang diberikan oleh penulis buku adalah dengan kembali ke muamalat, yang pilarnya adalah mata uang halal (dinar-dirham), terselenggaranya pasar (suq), aktifnya pedagang, kontrak syariah, serta unit-unit produksi mandiri. (hlm. 207-208). Ini adalah bukan solusi terhadap perbankan, tapi solusi kepada perekonomian umat. Sedangkan solusi terhadap kebutuhan finansial belum terjawab, padahal, saat ini banyak kebutuhan finansial yang memang tidak dapat diselesaikan sematamata dengan kontrak yang dijalankan secara normal. Misalnya saja, bagaimana keperluan tentang transfer uang, tentang hiwalah (pengiriman uang), keperluan untuk penngadaan aset, dan sebagainya.

Pengharaman uang fiat adalah suatu hal yang tidak sederhana, karena disamping permasaiahan cadangan logam mulia terbatas, juga mentalitas pelaku ekonomi dapat saja dengan mudah melakukan manipulasi terhadap dinar dan dirham. Sehingga, praktek pemakaian dinar dan dirham di masa Nabi dan shabat yang sangat ideal bukan hanya faktor mata uangnya, namun juga tingkat keimanan dan mentalitas masyarakat yang ada. Dalam masyarakat yang culas, bukan hanya kontrak-kontrak syariah saja yang disalahgunakan, tapi mata uang dinar dan dirham pun tidak mustahil dipalsukan.

Memang, kalau mau disadari dengan benar, seharusnya institusi keuangan (perbankan syariah) tidak dapat dilepaskan dari kondisi ekonomi. Bahwa perbankan syariah hanyalah salah satu unsur dari berbagai anasir ekonomi umat yang berjalan secara paralel. Kalau demikian, maka penyelesaiannya memang harus bersamaan dengan pengembangan ekonomi umat. Keuangan islam: Hanyalah pelengkap dari ekonomi ketuhanan, yang karenanya harus ada metode bisnis yang ilahiah. Dan hal ini haarus kembali kepada mentalitas manusianya.

Jika memang dipahami bahwa ekonomi Islam adalah faith-based atau moral-based economy, maka ketakwaan; etoka atau moralitas yang baik harus menjadi prasyaratnya. Karena jika tidak, yang terjadi adalah dorongan kepentingan profit saja. Jika dalam konteks Islam, maka ketakwaan ini memang telah terbukti dapat men-drive' ekonomi ke arah yang berbeda dari ekonomi mainstream kontemporer.

\section{Perbankan Syariah: Terbajak, bukan Infiltrasi}

Țuduhan Prof Umar Ibrahim Vadillo bahwa perbankan Islam adalah "kuda troya" yang disusupkan ke dalam Darul Islam (284) adalah tuduhan yang masih harus dipertanyakan. Ada dua fakta yang kalau dianalisa, justeru kesimpulannya kebalikan dari pendapat Vadillo. Pertama, bahwa ide tentang perbankan Isiam yang sudah mulai tersemai akhir paruh pertama dari abad 20 muncul dari kalangan muslim yang cukup gigih. Meski eksperimen Tabung Haji Malaysia sudah diintrodusir tahun 40 -an, tetapi baru sebagai sebuah gerakan kenegaraan (melibatkan policy negara) dimulai saatinagurasi Bank Central Pakistan.

Argumen lainnya adalah apa yang menjadi analisis dari Abdullah Saeed (1996). Menurut Abdullah Saeed, selain karena petro dolar, kebangkitan perbankan Islam juga karena fundamentalisme Islam. Hal ini didasarkan pada fakta bahwa para pioner yang menggagas perbankan Islam kebanyakan berasal dari anak benua (sub continent) yang berideologi fundamentalisme islam. 
Lebih dari itu, kecurigaan bahwa perbankan syariah (Islam) digunakan sebagai money laundering dari Islam fundamentalis, juga memberikan bukti bahwa justeru perbankan Islam lah yang diwaspadai Barat sebagai kebangkitan Islam, bukannya sebagai alat yang disusupkan oleh musuh Islam.

\section{Saran}

Jika dihayati, inti masalah dari semua ini adalah tentang belum terinseminasikannya ruh atáu semangat berekonomi syariah. Semua nilai ideal dari kontrak yang ada pada masa kejayaan Islam dapat disalahgunakan sedemikian rupa untuk membungkus kepentingan kapitalisme. Hal ini tentunya kembali kepada ada tidaknya mentalitas dan spirit bersyariah secara benar. Kontrak dan praktek muamalat memerlukan prasyarat, sebagaimana Nabi menegaskan bahwa yang diperlukan adalah keimanan terlebih dahulu sebelum seseorang menerima/ menjalani Islam. Jadi harus ada media untuk menumbuhkan semangat ini pada berbagai sektor ekonomi umat.

- Selanjutnya, regulasi yang kuat perlu disiapkan untuk menjaga kepatuhan syariah (syariah compliance), yang mampu 'memojokkan' investor pada ketundukan terhadap syariah, dan jika tidak bersedia, maka harus keluar dari bisnis berlabel syariah.

Terakhir, harus ada proyek inseminasi nilai-nilai akhlak ekonomi yang Islami yang kemudian dapat mendasari terjadinya praktek transaksi untuk lebih sesuai dengan prinsip syariah. Dan tidak mustahil nantinyajika diperlukan dua jenis perbankan syariah; bank komersial dan bank sosial atau pembangunan. Wallahu allam bishshawab. Agus Triyanta 